increased facilities for metallurgical education and to the growing importance of metallurgy. Difficulties are still met, however, when the research worker neglects to express himself simply and intelligibly, or the practical man may be unduly conservative as regards new ideas. Sir Henry quoted one example from his own experience in which prejudice was likely to obstruct the application of research in practice. In 1922 he heard incidentally that a small percentage of copper increased the corrosion-resisting properties of steel. Owing to the story, apparently, that if a puddler wished to get a fellow-worker into trouble, he threw a penny into the puddling furnace, it was difficult to get the material made. Finally, Sir Robert Hadfield accepted the order for a small cast of 'copper-bearing steel'. The metal was required for the smoke-box and ash-pan plates of locomotives, and it took a further six or seven years to show that better results were obtained than with ordinary steel, thus emphasising another point, that the practical test of a discovery should be started as quickly as possible without awaiting its full development. The research associations are invaluable in bringing together those directly engaged in industry and those conducting research.

\section{Land Utilisation Survey}

The Land Utilisation Survey of Britain organised by the London School of Economics and the Geographical Association, under the direction of Dr. L. Dudley Stamp, reports considerable progress during its first year. A general report on the work is given in the Bulletin of the Survey for February. After fifteen months' work, four counties in England and one in Scotland are completely finished and another eight counties are on the verge of completion. Of the 22,000 quarter-sheets of the 6-inch map of Great Britain, 3670 have been finished. This is good progress, when it is borne in mind that the work had to be organised from the start in every county and is entirely on a voluntary basis. The completed sheets are being reduced to a l-inch scale, and will then be printed in seven colours and issued by the Ordnance Survey. The numbering of these sheets will be on the basis of the popular edition of the 1-inch map. Sheet 114 (Windsor) is to be produced as an experimental sheet. While work is proceeding rapidly, in parts of the country, particularly in some of the counties of northern England, there are several areas in which little has yet been done. These blank areas include Gloucestershire, Essex, Huntingdon, several Welsh counties, the North Riding of Yorkshire, much of Northumberland, south-west Scotland, and large areas in the central and western Highlands. For these and other regions workers are still required.

\section{Natural History in Church Records}

I $T$ is strange from what odd quarters knowledge about the history of animal life may be gathered. This was apparently also the opinion of the vicar of Ridge, who refused permission to examine his parish books, on the ground that he found it difficult to conceive that payments for 'vermin' by parish No. 3255, VoL. 129] authorities could be of interest to anyone. For tunately no other refusal was met by Charles Oldham, and the results of his searches amongst church. wardens' records in Hertfordshire are some odd contributions to the history of vermin (Trans. Hertfords. Nat. Hist. Soc., vol. 19, pt. 2; 1931). Sparrows, which had increased enormously in num. bers because of the intensive cultivation of cereals, had a price upon their heads, and a record (Aldbury) of 1720 reads, " $\mathrm{Pd}$ for 6 Doz. of Sparrows heads ...1s."; and yet, at the same period, others were deliberately encouraging sparrows to multiply by setting up for their use curious receptacles, 'sparrow. pots', from which the young sparrows were taken for food. The most telling of all the records are those relating to the prices paid for the destruction of polecats. In 1721, at Chipping Barnet, $4 d$. was paid for two, in 1723 "for 4 Polecatt . . . 4s." was paid at East Barnet; these records, giving the extreme range of prices, indicate a common and almost worthless creature, and contrast with the demand in Scotland, where at one stage the price of a furrier's dozen of polecats reached $45 \mathrm{~s}$. Long before that time, in the mid-nineteenth century, when fur value of the polecat had made its pelt desirable, the pole. cats of Hertfordshire had been exterminated as 'vermin'

\section{Irish Forests}

THE opinion was widely held amongst Irish and English historians of the eighteenth and nineteenth centuries that Ireland was densely wooded down to the last five hundred years, and that the disappearance of the native forests was chiefly due to their exploitation by English adventurers, and the effects of the wars and disturbances during Elizabethan and Crom. wellian times. According to A. C. Forbes in his paper on "Some Legendary and Historical References to Irish Forests and their Significance", read before the Royal Irish Academy on Feb. 22, a review of the various authors who were responsible for this conclu. sion has shown that none can be considered sufficiently acquainted with Ireland to have been an authority on the subject. State papers and other documents indicate that the arrival of the Normans in the twelfth century found Ireland much as it is to-day. A point of considerable interest is the exact position of forest land under the forest laws of the Normans. This forest land was the waste or unenclosed portion of the country, and had no direct connexion with woods or timber trees. Two Irish deafforestation charters of the thirteenth century are in existence, but no record can be found of any proceeding for creating a forest, and $\mathrm{Mr}$. Forbes advanced the theory that the wastes of both Ireland and England were normally afforested or subject to forest laws at a remote period, and that these laws were gradually removed by deafforestation, for which money payments were frequently made to the Crown. Manwood's "Lawes of the Forest" is a doubtful guide on this subject. A further point of interest is the existence of Pinus sylvestris in the Irish flora during the historic period. While the pine was a dominant species when the older 
bogs were being laid down, its existence as an indigenous tree during the last thousand years is extremely doubtful.

\section{International Federation of Eugenic Organizations}

We have received a copy of the report of the ninth Conference of the International Federation of Eugenic Organizations, edited by the honorary administrative secretary, Mrs. C. B. S. Hodson, and published at 406 Fulham Road, London. The Conference met on Sept. 11-15, 1930, at Farnham, Dorset, and Larmer Tree Grounds, Tollard Royal, Wilts. Associated public meetings were held at the Tithe Barn, Hinton St. Mary, Dorset, at the invitation of Capt. Pitt-Rivers. The first conference, under the chairmanship of Sir Arthur Keith, considered the standardisation of human measurements, with opening papers by Miss M. L. Tildesley on the physical and Miss B. Schieffelin on the mental side. A conference on race crossing, with Dr. Alfred Ploetz in the chair, received contributions from Dr. Mjöen, Prof. C. G. Seligman, Dr. van Herwerden, Prof. Ruggles Gates, Dr. C. B. Davenport, and Prof. Eugen Fischer. At another session international programmes for research in racial psychiatry were presented by Prof. Rüdin, and in racial psychology by Prof. Seligman. An afternoon was devoted to heredity in man, with Prof. Gates in the chair, and contributions by Dr. P. J. Waardenburg, Dr. C. J. Bond, Dr. G. P. Frets, and Dr. Heuyer. The report includes a summary of the discussion on each paper. The last part is devoted to general reports, including a brief statement from twelve countries regarding work on the eugenic or dysgenic effects of the War, and statements concerning recent eugenic work in Czechoslovakia, Finland, South Africa, Holland, Germany, and Austria. Dr. H. H. Laughlin contributes a survey of eugenical work in the United States, Dr. Mjöen one for Norway, and Dr. Schrieber for France. This pamphlet of a hundred pages is a useful summary of work having anthropological and medical as well as eugenical aspects.

\section{Wood Decay in Motor-Cars in the Tropics}

THE practical importanee of this question is indicated in a brief note in the Philippine Journal of Science (vol. 46, No. 2) by C. J. Humphrey, mycologist to the Bureau of Science, Manila. He states that the depreciation of imported automobiles in the tropics from this cause reaches "a staggering figure in proportion to the investment". Most of the cars in the Philippines are American, a few come from Europe; in either case the woods used in their construction are almost exclusively temperate zone species, selected for other properties than their durability. The decay sets in as the result of moisture in the wood, but, under the conditions in the tropics in the rainy season, water almost inevitably penetrates and, in the humid atmosphere, does not easily dry out again. The author states that "six months under test conditions very highly favourable for decay will destroy for all practical use nearly all the temperate zone woods now used in American or Europeanmade cars ". Up to the present three species of the higher fungi have been observed fruiting on the rotting wood taken from cars; many more species probably contribute, but most of them are Hymenomycetes. The remedies for the trouble seem clear : either the use of the heartwood of durable species of timber, presumably tropical species, by the manufacturer, or else the non-durable timbers must be adequately treated with a preservative.

\section{Light upon Eggs}

ANALYsis shows that an inverse relation exists between the amount of daylight and the price of hens' eggs in successive months of the year. That in turn is correlated with the amount of food a hen may eat per day, so that the more light, the more food, and, other things being equal, the more eggs. Artificial lighting has been used on a large scale in the United States to shorten the long nights and induce hens to lay more, but it cannot be said to be a common practice in Britain. The results obtained by J. W. Rhys and Raymond T. Parkhurst at the National Institute of Poultry Husbandry suggest, however, that its use might well be extended (Bull. No. 6). During the winter months the 120 pullets under lights laid 950 more eggs than an equal number without lights. For the 48 weeks of the test the lighted pen yielded 1086 eggs more than the unlighted pen. The lighted pullets laid an average of 173.5 eggs and the unlighted $16 \mathrm{I} \cdot 0$ eggs. Financially, the "morning and evening lights' pen was most successful, the margin of profit over food and lighting costs being 11.58 pence a dozen eggs. Hens apparently give the best results under a 14-hour day.

\section{The First 'Sky-scraper'}

A PoINT of considerable interest in the history of architecture has just been settled by a joint committee of the American Institute of Architects and the Illinois Society of Architects, which, having watched the demolition of the Home Insurance Building in Chicago, has declared it to be "the first tall structure of metal construction". The essential feature of a 'sky-scraper' is the metal skeleton, defined as "a type of construction in which a metal frame or cage, composed of girders, beams, and columns, supports all internal and external loads and carries all stresses to the foundations ". Claims had been set up that the Tacoma Building of 1888 was the first tall metal skeleton building, but the committee states that in the Home Insurance Building there was "a complete skeleton framework, floor loads were carried by both interior and exterior columns, wall loads were transferred to columns, and columns were supported on independent footings ". The Home Insurance Building was designed by William Le Baron Jenney and was erected in 1885 . It has now been removed to make room for the gigantie Field Building in which 25,000 tons of steel will be used, but it will henceforth have its place in history as the first 'skyscraper'.

\section{Economic Uses of Beryllium}

Amonc the rarer metals which are light in weight and therefore suggest themselves for employment in the aircraft and automobile industries, beryllium

No. 3255, VoL. 129] 